\title{
The Representation of the South Pacific Convergence Zone in the Twentieth Century Reanalysis
}

\author{
Thomas Harvey And James A. Renwick \\ Victoria University of Wellington, Wellington, New Zealand \\ ANDREW M. LORREY \\ National Institute of Water and Atmospheric Research, Auckland, New Zealand \\ ARONA NGARI \\ Cook Islands Meteorological Service, Nikao, Rarotonga, Cook Islands
}

(Manuscript received 5 July 2018, in final form 24 November 2018)

\begin{abstract}
The South Pacific convergence zone (SPCZ) is the largest rainfall feature in the Southern Hemisphere, and is a critical component of the climate for South Pacific island nations and territories. The small size and isolated nature of these islands leaves them vulnerable to short- and long-term changes in the position of the SPCZ. Its position and strength is strongly modulated by El Niño-Southern Oscillation (ENSO), leading to large interannual variability in rainfall across the southwest Pacific including seasonal droughts and pluvials. Currently much of the analysis about SPCZ activity has been restricted to the satellite observation period starting in 1979. Here, the representation of the SPCZ in the Twentieth Century Reanalysis (20CR), which is a three-dimensional atmospheric reconstruction based only on surface observations, is discussed for the period since 1908. The performance of two versions of the 20CR (version 2 and version $2 \mathrm{c}$ ) in the satellite era is compared with other reanalyses and climate observation products. The 20CR performs well in the satellite era. Extra surface observations spanning the SPCZ region from the longitude of the Cook Islands has improved the representation of the SPCZ during 1908-57 between 20CRv2 and 20CRv2c. The well-established relationship with ENSO is observed in both the representation of mean SPCZ position and intensity, and this relationship remains consistent through the entire 1908-2011 period. This suggests that the ENSO-SPCZ relationship has remained similar over the course of the past century, and gives further evidence that 20CRv2c performs well back to 1908 over the southwest Pacific region.
\end{abstract}

\section{Introduction}

The South Pacific convergence zone (SPCZ) is the most extensive band of convection and precipitation in the Southern Hemisphere, extending southeast from the tropical west Pacific warm pool (WPWP) toward French Polynesia (Folland et al. 2002; Vincent 1994). The SPCZ is least well formed from May to October and is most well developed in the austral summer [December-February (DJF)]. It consists of two distinct components, a zonally oriented tropical component in the west, and a diagonally oriented subtropical component to the east (Haffke and Magnusdottir 2013; Niznik et al. 2015).

\footnotetext{
Corresponding author: james.renwick@vuw.ac.nz
}

Since the SPCZ was first recognized in satellite observations (e.g., Hubert 1961; Streten and Troup 1973), various hypotheses about the mechanisms controlling the diagonal orientation of the SPCZ have been put forth. Most investigations focused on tropical-midlatitude interactions arising from synoptic-scale disturbances and propagating tropospheric waves (e.g., Matthews 2012; Van Der Wiel et al. 2016; Widlansky et al. 2011). Rossby waves emanating from the subtropical jet near Australia are deflected toward the upper-tropospheric westerly winds over the eastern equatorial Pacific Ocean (Matthews 2012; Van Der Wiel et al. 2016). These waves elongate on a northwest-southeast axis of orientation in the SPCZ region, and can trigger convection when they pass over the warm waters of the tropical southwest Pacific Ocean. 
However, Rossby waves can propagate only when uppertropospheric westerly winds are present during the austral summer, helping to explain why the SPCZ is most pronounced at this time of year (Matthews 2012; Van Der Wiel et al. 2016; Widlansky et al. 2011).

The influence of the South Pacific anticyclone (SPA) and the South American continent as controls on the eastern margin of the SPCZ has also been examined (Kiladis et al. 1989; Lintner and Neelin 2008; Takahashi and Battisti 2007). Kiladis et al. (1989) modeled the SPCZ after removing both Australia and South America in climate simulations, and found that the absence of South America had no strong effect on the position of the SPCZ. However, Takahashi and Battisti (2007) suggested that the interaction of the subtropical westerlies with the Andes causes a region of subsiding air, resulting in the formation of the SPA, a permanent high pressure feature of the large-scale circulation of the Southern Hemisphere. The western edge of the SPA forms the eastern SPCZ margin, and the observed northwestsoutheast tilt arises from the orientation of southeasterly trade winds in the southwest Pacific. In addition, the variation in trade wind intensity has been investigated as a control on the eastern edge of the SPCZ (Lintner and Neelin 2008), where reduced trade winds are associated with an eastward expansion of tropical convection and precipitation (e.g., during El Niño conditions).

The SPCZ responds to different modes of climate variability on various time scales. It is influenced by the Madden-Julian oscillation (MJO; Madden and Julian 1994) on intraseasonal time scales (Matthews et al. 1996), the El Niño-Southern Oscillation (ENSO) on interannual time scales (Borlace et al. 2014), and the interdecadal Pacific oscillation (IPO) on decadal time scales (Folland et al. 2002). This main convection zone also modulates the formation and distribution of tropical cyclones in the southwest Pacific, with tropical cyclone genesis and subsequent storm movement to the region south of the SPCZ (Diamond et al. 2013; Vincent et al. 2011).

The SPCZ plays an influential role in the climate of isolated South Pacific nations, being a major control on rainfall distribution (Cai et al. 2012; Lorrey et al. 2012; Niznik et al. 2015; Vincent et al. 2011). Strong rainfall gradients at the edges of the SPCZ mean that any shortor long-term changes in the position of convection can lead to dramatic changes in hydrological and climatic conditions for small island nations in the southwest Pacific (Cai et al. 2012; Vincent et al. 2011). Floods and droughts associated with variation in SPCZ position can cause severe socioeconomic impacts, such as damage to agriculture and civil infrastructure, as a result of heavyrainfall-induced flooding (Lorrey et al. 2012).

Numerous studies have shown that the SPCZ varies on interannual time scales with ENSO (e.g., Borlace et al. 2014; Brown et al. 2011; Folland et al. 2002; Kidwell et al. 2016; Trenberth 1976; Vincent et al. 2011). During La Niña conditions, cooler SSTs and increased trade winds in the eastern and central Pacific Ocean push the SPCZ associated convection southwest of its mean climatological position (Collins et al. 2010; McPhaden et al. 2006; Wang et al. 2017). During El Niño conditions, warm SST anomalies in the eastern and central Pacific Ocean reduce trade wind strength, via weakened Walker circulation (Wang et al. 2017). As a result, SPCZ-related convection occurs farther north and east of its mean climatological position.

The SPCZ usually maintains a diagonal orientation into the subtropics, despite ENSO-related mean positional changes (Vincent et al. 2011). However, three recent El Niño events (1982/83, 1991/92, and 1997/98) showed an SPCZ that had an extreme equatorward swing, with an almost zonal orientation (e.g., Borlace et al. 2014; Vincent et al. 2011 and others). That orientation was attributed to strong eastern equatorial Pacific Ocean warming and a reduced zonal SST gradient, allowing the main area of convection to shift toward South America and the eastern portion of the SPCZ to move north (Borlace et al. 2014; Kidwell et al. 2016). Concurrently, reduced convection from cold SST anomalies in the western equatorial Pacific push the western end of the SPCZ south, producing the zonal orientation of the SPCZ across the tropical Pacific Ocean (Borlace et al. 2014; Kidwell et al. 2016; Vincent et al. 2011).

How the SPCZ will respond to future warming and potential changes in interannual to multidecadal variability is still an open question. Past occurrences of a near-zonal orientation of the SPCZ during extreme El Niño events (Cai et al. 2012) need to be better understood, given the uncertainty about how ENSO will respond in a warmer world (IPCC 2013). These impacts mean that understanding the long-term history of the SPCZ is important for assessing how future changes related to the convection zone changes could affect vulnerable South Pacific nations. Here, we report on the ability of different iterations of extended reanalyses without radiosondes (20CR; Compo et al. 2011) to represent SPCZ locations in the presatellite era, and describe ENSO-related variability of the convection zone throughout the twentieth century. Section 2 details the data and methods used. Section 3 covers all results, including ENSO sensitivity of the SPCZ, and section 4 contains a discussion and conclusions. 
TABLE 1. Details of stations where weather observations were added between 20CRv2 and 20CRv2c. Data supplied by ACRE Pacific, led out of the National Institute of Water and Atmosphere (NIWA), and in collaboration with the Cook Islands Meteorological Service.

\begin{tabular}{llcccc}
\hline \multicolumn{1}{c}{ Station name } & \multicolumn{1}{c}{ Lat } & \multicolumn{1}{c}{ Lon } & Time period start & Time period end & ISPD version \\
\hline Rarotonga Radio Station & $21.19^{\circ} \mathrm{S}$ & $158.81^{\circ} \mathrm{W}$ & 1 May 1934 & 31 May 1950 & 3 \\
Penrhyn & $9^{\circ} \mathrm{S}$ & $158.05^{\circ} \mathrm{W}$ & $13 \mathrm{Jan} 1937$ & 31 Aug 1996 \\
Pukapuka & $10.88^{\circ} \mathrm{S}$ & $165.82^{\circ} \mathrm{W}$ & 1 Nov 1929 & $18 \mathrm{Jul} 2000$ & 3 \\
Rarotonga Aero & $21.18^{\circ} \mathrm{S}$ & $159.8^{\circ} \mathrm{W}$ & $1 \mathrm{Jun} 1948$ & 30 Sep 2010 \\
Raro Avarua & $21.2^{\circ} \mathrm{S}$ & $159.78^{\circ} \mathrm{W}$ & 1 Feb 1929 & 31 Dec 1933 \\
\hline
\end{tabular}

\section{Data and methodology}

\section{a. Datasets}

Although many phenomena influence, or interact with, the SPCZ, only the ENSO-SPCZ relationship is investigated here. The main datasets used in this study were the Twentieth Century Reanalysis (20CR) version 2 (20CRv2) and version 2c (20CRv2c) products. The 20CR project was developed to provide a global reanalysis that spanned the entire twentieth century, while assimilating only physical surface observations (Compo et al. 2011). This approach aims to avoid artificial jumps seen in many reanalyses that are associated with the changing nature of the observational record (e.g., the introduction of satellite data in the late 1970s).

Data from five stations in the South Pacific (Table 1) were added to the International Surface Pressure Databank (ISPD) between 20CRv2 (ISPD version 2) and 20CRv2c (ISPD version 3.2.9; Cram et al. 2015). The analysis performed here helps determine if these extra observations, provided as a contribution from the National Institute of Water and Atmosphere (NIWA) to the Atmospheric Circulation Reconstructions over the Earth (ACRE) initiative, helped improve the depiction of the SPCZ between product iterations.

We compared the two 20CR products with five other reanalysis and observational satellite data: the European Centre for Medium-Range Weather Forecasts (ECMWF) interim reanalysis (ERA-Interim; Dee et al. 2011), the National Centers for Environmental Prediction-National Center for Atmospheric Research Reanalysis 1 (NCEPNCAR1; Kalnay et al. 1996), the Global Precipitation Climatology Project (GPCP; Adler et al. 2003), the Tropical Rainfall Measuring Mission (TRMM) 3B42 version 7 (Huffman et al. 2007), and the outgoing longwave radiation (OLR) dataset from the National Oceanic and Atmospheric Administration (NOAA; Liebmann and Smith 1996).

We also used the multivariate ENSO index (MEI; Wolter and Timlin 1998) to analyze the SPCZ-ENSO relationship. All bimonthly values from November to April were averaged to create an austral warm season MEI value, a method similar to that used by Haffke and Magnusdottir (2013). Quintiles of the MEI were used to categorize each season according to the phase of ENSO. The five quintiles were classified as strong La Niña, weak La Niña, neutral, weak El Niño, and strong El Niño, respectively.

\section{b. Methodology}

All global datasets were interpolated onto a $1.5^{\circ} \times$ $1.5^{\circ}$ horizontal grid covering the area from $0^{\circ}-35^{\circ} \mathrm{S}$ to $150^{\circ} \mathrm{E}-120^{\circ} \mathrm{W}$ and an area of the southwest Pacific that includes both the tropical and subtropical components of the SPCZ (Fig. 1).

The comparison of reanalysis and satellite products was performed for the common period 1979-2011, during the primary austral summer months (DJF). Note, however, that the TRMM dataset begins in 1998. The 20CR comparison and ENSO analysis are both performed for period 1908-2011.

\section{c. Identification of the SPCZ}

The DJF average 500-hPa vertical motion (omega, $\mathrm{Pa} \mathrm{s}^{-1}$ ) field was used to indicate the position and intensity of the SPCZ in the reanalysis products. The position of the SPCZ was identified as a line of minimum 500-hPa omega, minimum OLR, and maximum precipitation (TRMM and GPCP), an approach similar to that used by Brown et al. (2013). At each longitude increment $\left(1.5^{\circ}\right)$, the latitude of the minimum (or maximum, for precipitation) was identified, resulting in a series of points that could be connected from west to east in a line representing the SPCZ location. The raw SPCZ location values were smoothed with two applications of a 13-point low-pass filter (Trenberth et al. 2007, see their appendix 3.A). Figure 2 shows an example of the resulting SPCZ location.

A very similar approach was used to identify the intensity of the SPCZ. The greatest intensity (largest magnitude) of each SPCZ metric was determined at each $1.5^{\circ}$ longitude increment, and the resulting line was smoothed twice using the same 13-point low-pass filter. The intensity values were not calculated at the locations on the smoothed line of the SPCZ position, as these values would not represent the greatest intensity across the analysis domain. 


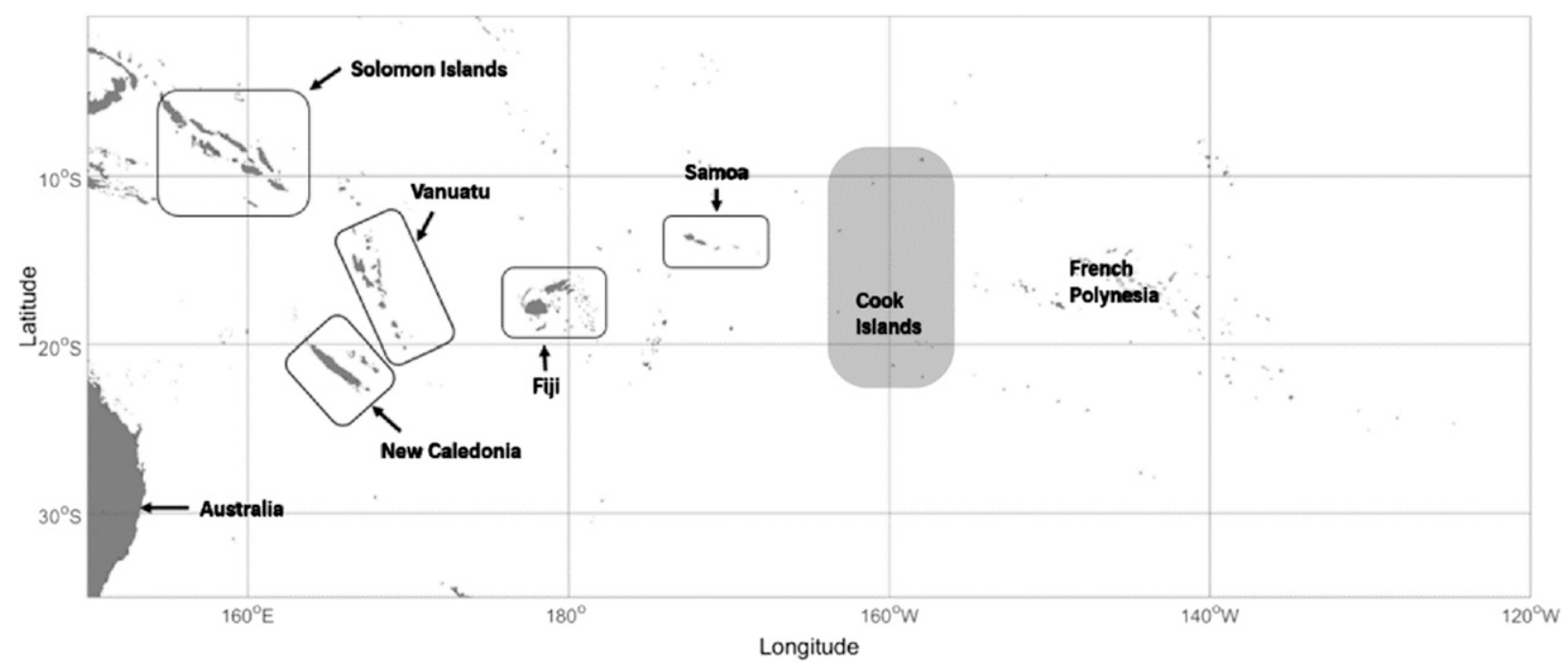

FIG. 1. Base map showing the region that the SPCZ is analyzed in for this study. The map covers an area of the southwest Pacific from $150^{\circ} \mathrm{E}$ to $120^{\circ} \mathrm{W}$ in longitude and $0^{\circ}$ to $35^{\circ} \mathrm{S}$ in latitude. Cook Islands region (including northern and southern island groups) shaded in gray.

\section{Results}

\section{a. Intercomparison of reanalysis and satellite products}

Reanalysis and satellite products were compared using the DJF averages during 1979-2011, a time when all analyzed products overlapped. All the products showed good agreement on the mean position of the SPCZ, especially west of $160^{\circ} \mathrm{W}$ (Fig. 3).

The NCEP-NCAR1 reanalysis showed the most zonally oriented SPCZ, being south of the others between $150^{\circ} \mathrm{E}$ and $\sim 165^{\circ} \mathrm{W}$, and situated north of all other products east of $\sim 155^{\circ} \mathrm{W}$. The NCEP-NCAR 1 is the oldest reanalysis used in this study, and the issue of SPCZ zonality was identified several times in the literature (Brown et al. 2012, 2013; Niznik et al. 2015). The OLR field is in good agreement with the other products west of $\sim 150^{\circ} \mathrm{W}$, but diverges to the south in the eastern part of the analysis domain. This could be a result of the breakdown of the close relationship between OLR and tropical precipitation as the SPCZ becomes more subtropical in the eastern part of the analysis domain (see Van Der Wiel et al. 2015).

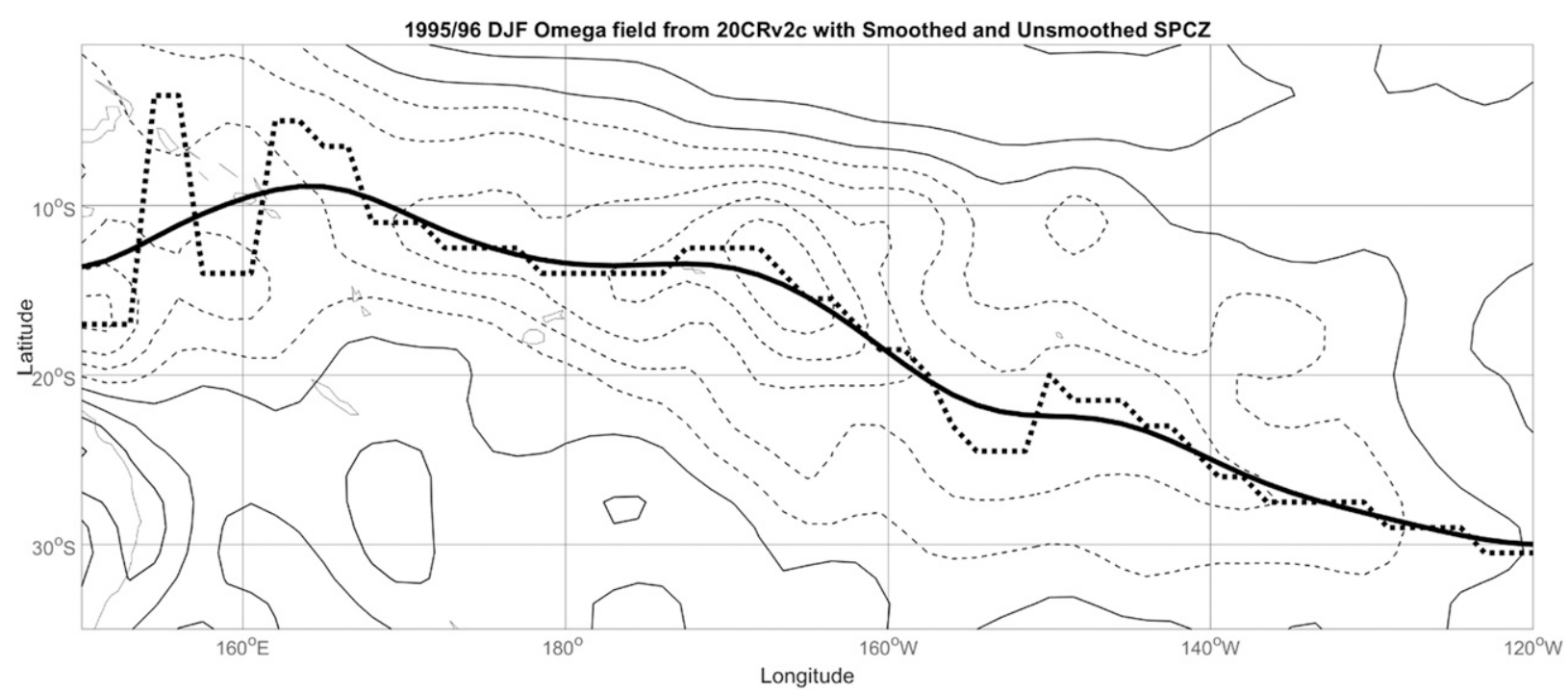

FIG. 2. Example showing SPCZ location calculation. Contours are the DJF 1995/96 average 500-hPa omega fields (Pa s ${ }^{-1}$, contour interval 0.02 , gray contours positive, dashed contours negative). The thick dotted line shows the latitude of minimum omega at each longitude ( $1.5^{\circ}$ increments), and the thick black line shows the filtered/smoothed version. 


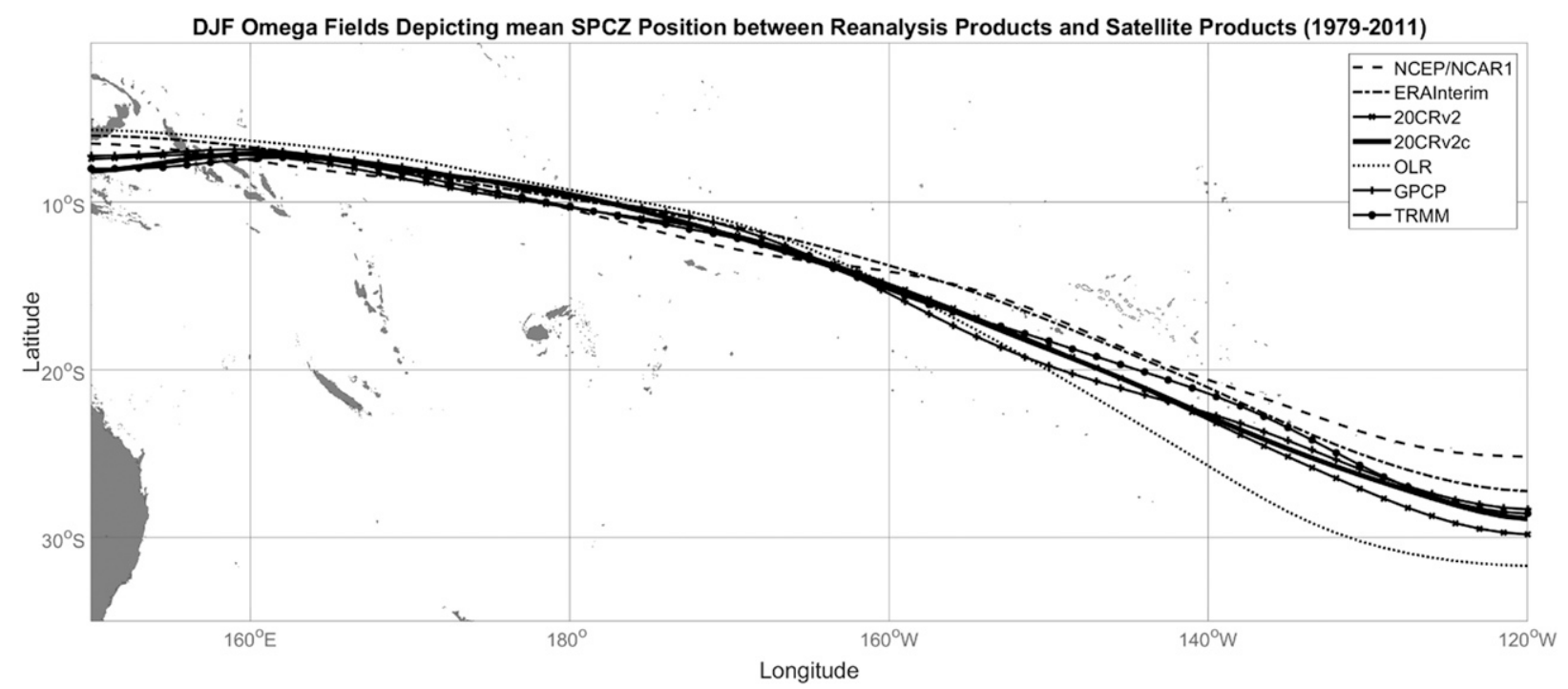

FIG. 3. The mean DJF location of the SPCZ from 1979 to 2011 for several reanalysis products. Analysis used the 500-hPa omega field for the austral summer period.

Regardless of these discrepancies, all of the analyzed products show good agreement when depicting the mean position of the SPCZ for the 1979-2011 DJF period. Comparing interannual SPCZ location variability at every $6^{\circ}$ longitude (about $650 \mathrm{~km}$ at $10^{\circ} \mathrm{S}$ ) spaced across the southwest Pacific shows highly significant temporal correlations $[r=0.6-0.9$, $n=61$, degrees of freedom $(\mathrm{df})=59, p<0.01]$ between 20CRv2c and the ERA-Interim, GPCP, and OLR products (Table 2). This indicates these four gridded data products depict similar interannual changes in the position of the SPCZ across the analysis domain.

\section{b. Comparison of Twentieth Century Reanalysis products}

The comparison of 20CRv2 and 20CRv2c showed that the position of the SPCZ is very similar between the two products during 1958-2011, as they should be, while there are some differences from 1908 to 1957 (Fig. 4). The close depiction of the SPCZ between 20CRv2 and 20CRv2c for 1958-2011 is most likely a result of the underlying data being very similar between the two products for this time period.
For 1908-57, there is a difference in average SPCZ location between the two products across the majority of the region, before they align in the far east of the domain (Fig. 4a). The SPCZ position is represented differently between $20 \mathrm{CRv} 2$ and $20 \mathrm{CRv} 2 \mathrm{c}$ from $\sim 160^{\circ} \mathrm{E}$ to the international date line (IDL) (the "western section"), and from the $\sim 170^{\circ}$ to $\sim 155^{\circ} \mathrm{W}$ (the "eastern section"). To determine whether these two areas showed a statistically significant difference between the two products, a two sample $t$ test was performed using the annual time series of latitude locations (Table 3).

This test was initially performed at the $95 \%$ significance level, and it showed no statistically significant difference between 20CRv2 and 20CRv2c across the longitudinal range of the SPCZ area. However, at the $90 \%$ significance level, a significant difference existed between the two products from $\sim 163^{\circ}$ to $\sim 167^{\circ} \mathrm{E}$, and $\sim 168^{\circ}$ to $\sim 166^{\circ} \mathrm{W}$. In addition, the ensemble spread of the mean DJF 500-hPa omega field (20CRv2c20CRv2, not shown) showed that model uncertainty has decreased for $20 \mathrm{CRv} 2 \mathrm{c}$ between $5^{\circ}$ and $20^{\circ} \mathrm{S}$ across the majority of the analysis domain. This analysis, along with the differing depiction of the SPCZ between 20CRv2 and 20CRv2c (Fig. 4a), all suggest an

TABLE 2. 20CRv2c temporal correlations with (top) OLR, (middle) GPCP, and (bottom) ERA-Interim. Correlations are for SPCZ position every $6^{\circ}$ longitude across the domain of analysis for DJF during the 1979-2011 period.

\begin{tabular}{|c|c|c|c|c|c|c|c|c|c|c|c|c|c|c|c|c|}
\hline & $150^{\circ} \mathrm{E}$ & $156^{\circ} \mathrm{E}$ & $162^{\circ} \mathrm{E}$ & $168^{\circ} \mathrm{E}$ & $174^{\circ} \mathrm{E}$ & $180^{\circ}$ & $174^{\circ} \mathrm{W}$ & $168^{\circ} \mathrm{W}$ & $162^{\circ} \mathrm{W}$ & $156^{\circ} \mathrm{W}$ & $150^{\circ} \mathrm{W}$ & $144^{\circ} \mathrm{W}$ & $138^{\circ} \mathrm{W}$ & $132^{\circ} \mathrm{W}$ & $126^{\circ} \mathrm{W}$ & $120^{\circ} \mathrm{W}$ \\
\hline OLR & 0.70 & 0.80 & 0.84 & 0.88 & 0.90 & 0.89 & 0.85 & 0.86 & 0.85 & 0.80 & 0.78 & 0.71 & 0.75 & 0.81 & 0.84 & 0.87 \\
\hline GPCP & 0.80 & 0.84 & 0.75 & 0.82 & 0.93 & 0.86 & 0.85 & 0.89 & 0.85 & 0.67 & 0.68 & 0.79 & 0.83 & 0.80 & 0.87 & 0.90 \\
\hline ERA & 0.64 & 0.80 & 0.84 & 0.86 & 0.89 & 0.90 & 0.92 & 0.92 & 0.89 & 0.76 & 0.75 & 0.82 & 0.80 & 0.83 & 0.90 & 0.92 \\
\hline
\end{tabular}



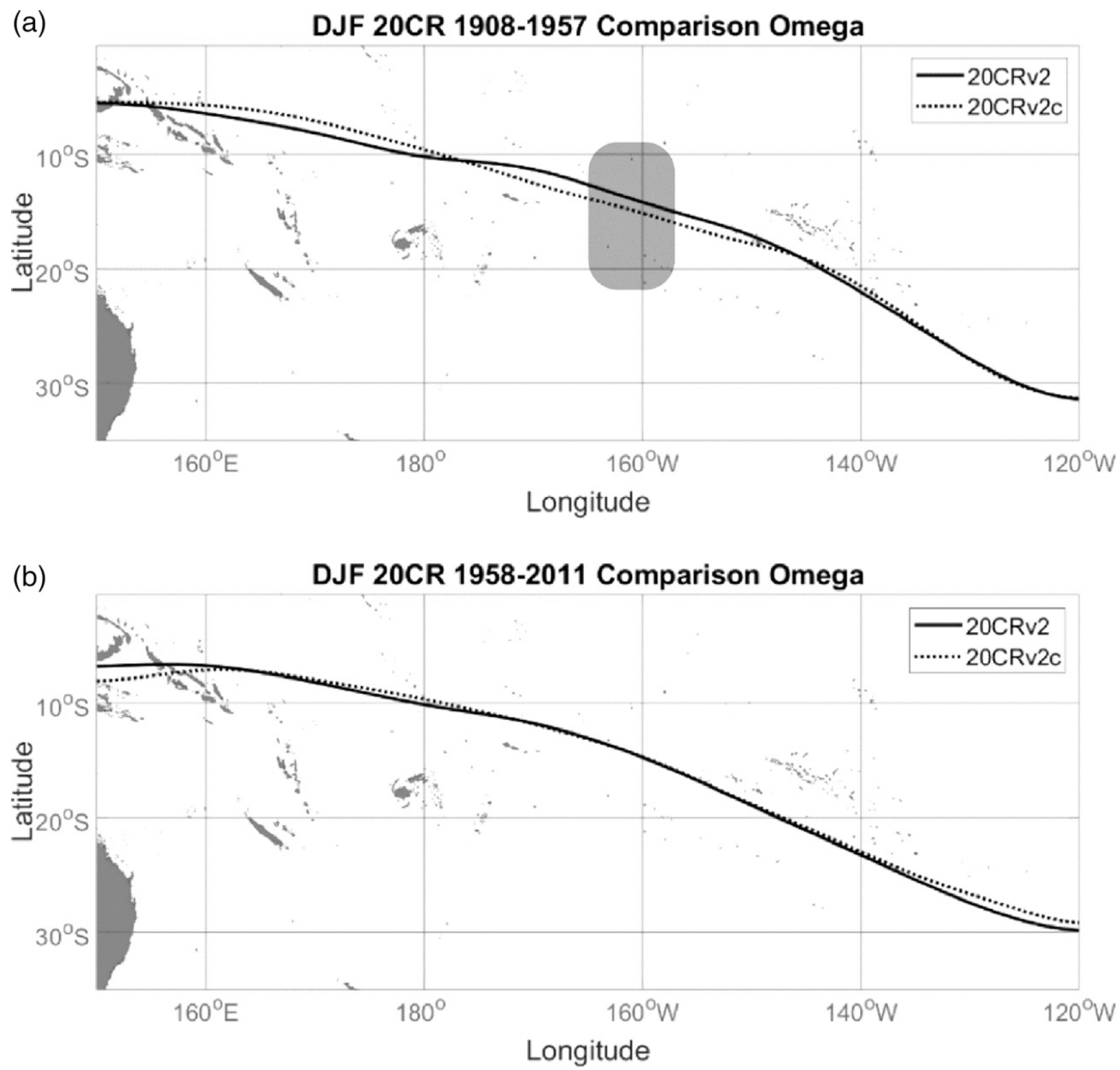

FIG. 4. Comparison of mean DJF SPCZ position between 20CRv2 and 20CRv2c for (a) 1908-57 and (b) 1958-2011. Gray shading in (a) indicates region where surface pressure observations from the Cook Islands Meteorological Service were added into the International Surface Pressure Databank.

improvement in the spatial representation for the SPCZ in 20CRv2c for the 1908-57 period.

c. Case study: ENSO and the SPCZ

\section{1) Position}

The 20CRv2c representation of the SPCZ was used to investigate the ENSO-SPCZ relationship for the full 1908-2011 DJF period (Fig. 5). The analysis showed a distinct latitudinal (north-south) movement in SPCZ position across the range of ENSO states defined for this study.
The mean position of the SPCZ for strong El Niño (SEN) years is situated north of all other determined ENSO phases across the entire analysis domain, with the exception of the very far west, where it lies slightly south of the position in weak El Niño (WEN) years. It has a zonal orientation from $150^{\circ} \mathrm{E}$ to the IDL before it takes on a diagonal orientation into the subtropics that is characteristic of the SPCZ. This zonal orientation means that the most equatorward point of the mean SPCZ position occurs near $170^{\circ} \mathrm{E}$, instead of near the far west of the analysis domain. The mean position of the SPCZ during 
TABLE 3. Comparison of $p$ values for the "western section" and the "eastern section" where the SPCZ position appears different between $20 \mathrm{CRv} 2$ and 20CRv2c. The $p$ values in bold are significant at the $90 \%$ level.

\begin{tabular}{|c|c|c|c|c|c|c|c|c|c|c|c|}
\hline \multicolumn{12}{|c|}{ Western section where $20 \mathrm{CRv} 2$ and $20 \mathrm{CRv} 2 \mathrm{c}$ are visually different } \\
\hline Lon & $162^{\circ} \mathrm{E}$ & $163.5^{\circ} \mathrm{E}$ & $165^{\circ} \mathrm{E}$ & $166.5^{\circ} \mathrm{E}$ & $168^{\circ} \mathrm{E}$ & $169.5^{\circ} \mathrm{E}$ & $171^{\circ} \mathrm{E}$ & $172.5^{\circ} \mathrm{E}$ & $174^{\circ} \mathrm{E}$ & $175.5^{\circ} \mathrm{E}$ & $177^{\circ} \mathrm{E}$ \\
\hline$p$ value & 0.109 & 0.098 & 0.095 & 0.099 & 0.107 & 0.118 & 0.130 & 0.143 & 0.158 & 0.180 & 0.219 \\
\hline \multicolumn{12}{|c|}{ Eastern section where $20 \mathrm{CRv} 2$ and $20 \mathrm{CRv} 2 \mathrm{c}$ are visually different } \\
\hline Lon & $169.5^{\circ} \mathrm{W}$ & $168^{\circ} \mathrm{W}$ & $166.5^{\circ} \mathrm{W}$ & $165^{\circ} \mathrm{W}$ & $163.5^{\circ} \mathrm{W}$ & $163^{\circ} \mathrm{W}$ & $161.5^{\circ} \mathrm{W}$ & $160^{\circ} \mathrm{W}$ & $158.5^{\circ} \mathrm{W}$ & $157^{\circ} \mathrm{W}$ & $155.5^{\circ} \mathrm{W}$ \\
\hline$p$ value & 0.104 & 0.088 & 0.093 & 0.115 & 0.154 & 0.198 & 0.234 & 0.250 & 0.246 & 0.234 & 0.228 \\
\hline
\end{tabular}

WEN years shows a similar spatial pattern to that of SEN years. The SPCZ also appears zonally oriented in the west of the analysis domain; however, the most equatorward point occurs slightly west (and south) than during SEN years. The major difference in the average position of the SPCZ between these two ENSO phases is the magnitude of equatorward displacement, with greater displacement being observed during SEN years.

The mean position of the SPCZ during strong La Niña (SLN) years is farther south than other ENSO phases across the entire SPCZ region. It has a zonal orientation west of $160^{\circ} \mathrm{E}$ and is diagonal to the east of this line. The mean position of the SPCZ during weak La Niña (WLN) years shows a similar spatial pattern to that of SLN years; however, the position most closely resembles that seen during neutral conditions.

SPCZ spatial positioning in relation to ENSO has patterns similar to what is described previously (e.g., Borlace et al. 2014; Vincent et al. 2011). There is significant northward departure from the mean SPCZ position during SEN conditions, with significant southward departure occurring during SLN conditions. This same pattern of movement is also seen during WEN and WLN conditions; however, the magnitude of movement is not as dramatic. Performing this analysis for just the 1908-57 period (not shown) showed that this pattern of SPCZ behavior in relation to ENSO has remained similar throughout the entire twentieth, and early twenty-first centuries.

\section{2) INTENSITY}

There was also a noticeable ENSO influence present in the intensity of the SPCZ for the 1908-2011 DJF period (Fig. 6). Using 500-hPa omega as a proxy for convective intensity, the years in which strong El Niño conditions are present show a different pattern to other phases of ENSO, with the location of maximum convective intensity shifting and mean intensity also reaching different magnitudes across the convection zone.

Anomalous SPCZ intensity is particularly evident when examining SEN conditions, where the location of

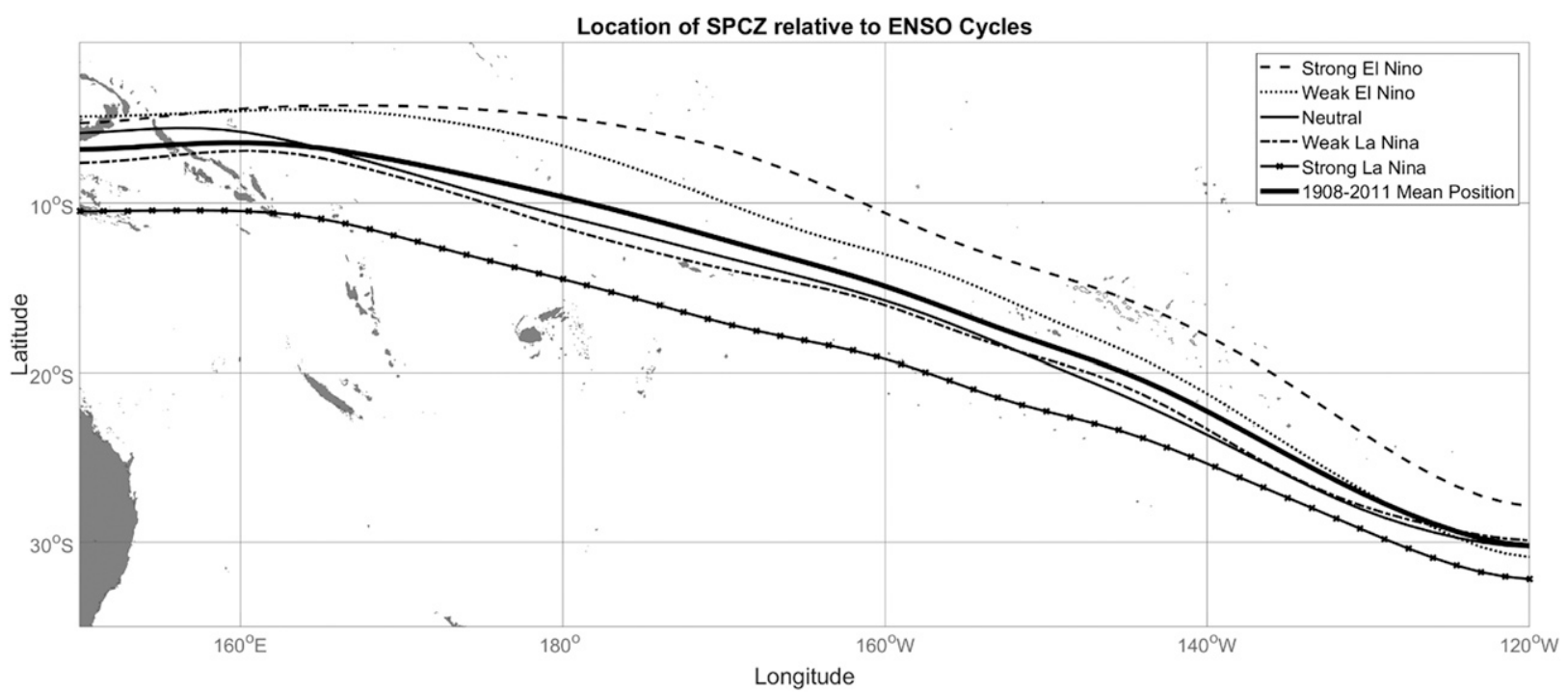

FIG. 5. The mean DJF SPCZ position based on ENSO phase from 1908 to 2011 based on 20CRv2c using maximum 500-hPa omega at each line of longitude from 20CRv2c. 


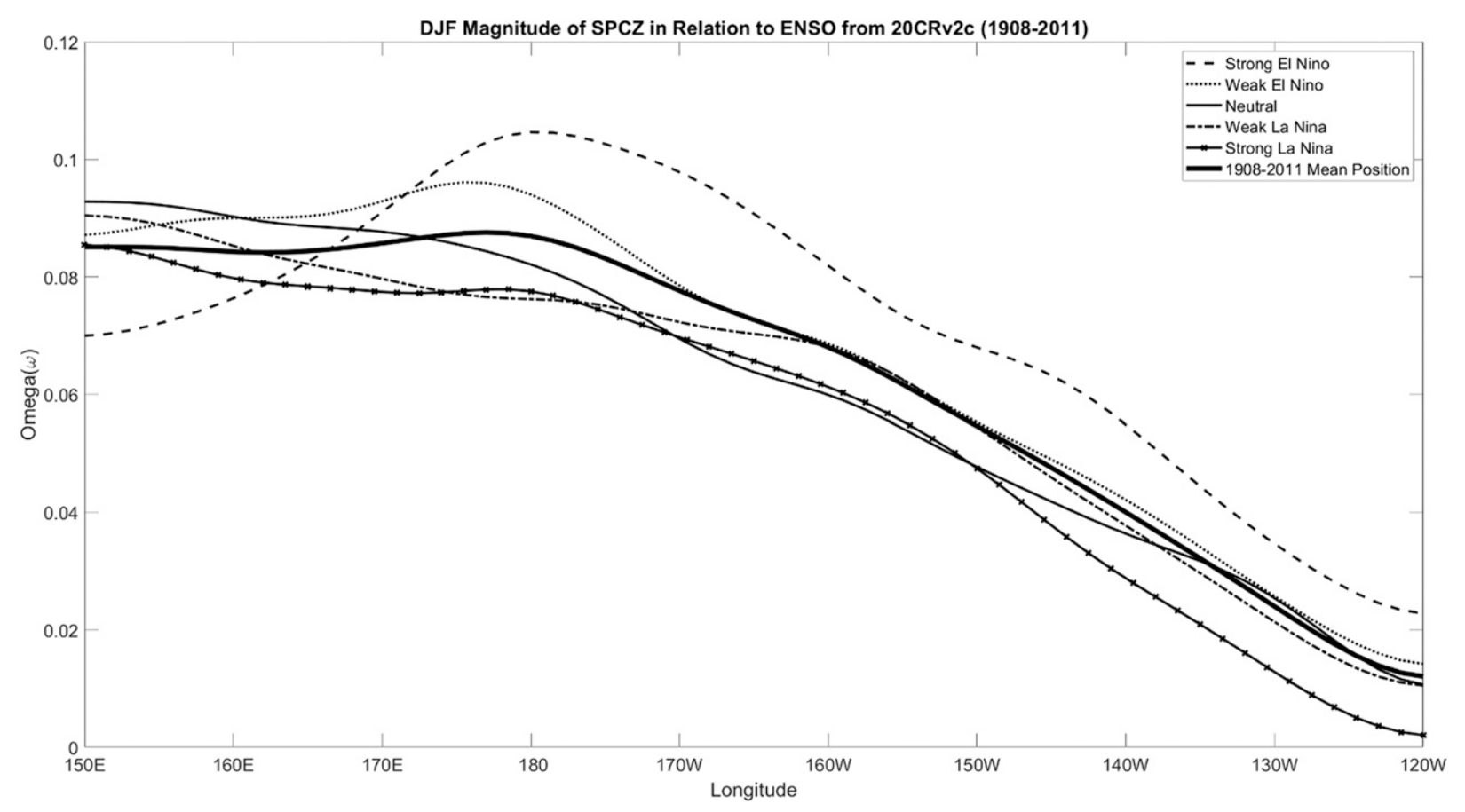

FIG. 6. The mean DJF SPCZ intensity based on ENSO phase from 1908 to 2011 using maximum 500-hPa omega at each line of longitude from 20CRv2c.

maximum vertical motion occurs farthest east (near the IDL), and reaches a higher level than the other ENSO phases. The intensity of convection during SEN conditions is also considerably lower in the far west of the analysis domain at $150^{\circ} \mathrm{E}$. During WEN conditions, the pattern of SPCZ intensity is similar to that seen during SEN conditions. However, the maximum intensity occurs slightly farther west at $\sim 175^{\circ} \mathrm{E}$ and at a lower magnitude. The intensity of SPCZ convection during WEN conditions is not as low at $150^{\circ} \mathrm{E}$ as seen during SEN conditions, instead it is comparable to the other ENSO phases.

The maximum intensity of SPCZ-related convection occurs at the far west of the analysis domain $\left(150^{\circ} \mathrm{E}\right)$ for all other conditions that have been defined at neutral, WLN, and SLN. From this point, the intensity decreases toward the east. Overall, the magnitude of maximum SPCZ convection during SLN conditions is the lowest of all determined ENSO phases; however, the intensity is comparable to that of neutral and WLN conditions from near the IDL to $\sim 165^{\circ} \mathrm{W}$.

The pattern of maximum SPCZ associated convection in relation to ENSO phases shows that the maximum intensity increases, and occurs farther east during El Niño conditions, while decreasing, and occurring at the western edge of the analysis domain during all other ENSO conditions.

\section{Discussion and conclusions}

This study compared the representation of the SPCZ for two 20CR products (20CRv2 and 20CRv2c) with other reanalysis and satellite products. The aim was to investigate whether the 20CR products, which use only surface observations in the data assimilation process (Compo et al. 2011), could accurately depict the position of the SPCZ, and therefore indicate whether they can be used to faithfully outline long-term SPCZ history.

When using 500-hPa omega, the 1979-2011 DJF SPCZ position showed a close fit to the other reanalyses and observational satellite products (Fig. 3). NCEPNCAR1 and the OLR representation diverged most from the other five products, particularly in the eastern subtropical component of the SPCZ. The zonal bias of NCEP-NCAR1 is most likely related to the tendency of many models to represent the SPCZ too zonally, as it is the oldest reanalysis product analyzed (e.g., Brown et al. 2012, 2013; Niznik et al. 2015; Vincent et al. 2011). The southward movement of the OLR field east of $150^{\circ} \mathrm{W}$ is most likely attributed to decreased atmospheric and surface temperatures in the subtropics causing a breakdown of the strong relationship that exists between minimum OLR and precipitation in the tropics (Van Der Wiel et al. 2015). However, regardless of the differences observed in these two products, the depiction of the mean DJF 1979-2011 SPCZ position is very similar for 
all products analyzed. In addition, temporal correlations that are significant across the study domain show that the products capture similar mean SPCZ locations and interannual variability characteristics (Table 2).

The 20CR products incorporate only surface observations, so the $500-\mathrm{hPa}$ omega field is derived from these through model dynamics. Regardless of this potential limitation, the SPCZ appears similar to that in reanalyses and satellite products that also contain upper atmosphere observations. The similarities in the depiction of southwest Pacific atmospheric circulation during the satellite era suggest a good degree of threedimensional realism for $20 \mathrm{CR}$ product, and that it is feasible to base reanalyses on surface observations alone (Compo et al. 2011). While it was deemed feasible to use the $20 \mathrm{CRv} 2 \mathrm{c}$ product for analysis extending back to 1908 , broader consideration suggests that just because the product performs well from 1979 to 2011 does not necessarily mean the performance will remain as accurate for the entire twentieth century.

The mean position of the SPCZ for the two 20CR products are very similar during 1958-2011, while there are differences between 20CRv2 and 20CRv2c for 1908-57. The close depiction between the two products during 1958-2011 suggests that the underlying data that were assimilated into the model that produced the reanalysis were very similar. The performance of 20CR products relies heavily on spatiotemporal data density (Compo et al. 2011), so this result could be expected, as the most recent observations from the late twentieth century comprise the bulk of the dataset and are more accessible, having likely been assimilated into both 20CRv2 and 20CRv2c. Recent data rescue efforts to improve performance of $20 \mathrm{CR}$ products are largely focused on earlier periods (pre-1960), especially in the Southern Hemisphere, where data sparseness is significantly more prevalent.

There was a visual difference seen between 20CRv2 and 20CRv2c in the representation of the SPCZ position for 1908-57. The main difference was observed from $\sim 160^{\circ} \mathrm{E}$ to the IDL (the "western section"), and from $\sim 170^{\circ}$ to $\sim 155^{\circ} \mathrm{W}$ (the "eastern section"). The difference was found to be statistically significant at the $90 \%$ level (two-tailed $t$ test) between $\sim 163^{\circ}$ and $\sim 167^{\circ} \mathrm{E}$, as well as $\sim 168^{\circ}$ to $\sim 166^{\circ} \mathrm{W}$, suggesting an important change was made to 20CRv2c for 1908-57 for the SPCZ region. Comparing the ensemble spread of the mean DJF 500-hPa omega field for the 20CR products (20CRv2c-20CRv2) showed decreased model uncertainty for $20 \mathrm{CRv} 2 \mathrm{c}$ between $5^{\circ} \mathrm{S}$ and $20^{\circ} \mathrm{S}$ across the majority of the SPCZ area. This supports the assertion that the increased spatiotemporal coverage of observations from remote islands in the southwest Pacific assisted the data assimilation process and realism of the atmospheric circulation output in 20CRv2c. Hence we infer that the addition of five stations of data from the Cook Islands (Table 1) into ISPD 3.2.9 between 20CRv2 and 20CRv2c in 1908-58 was an important contribution to $20 \mathrm{CR}$ for showing past SPCZ activity.

Analysis of the ENSO-SPCZ relationship was investigated using 20CRv2c for the 1908-2011 DJF period, and was performed for both mean SPCZ position and intensity. As the ENSO-SPCZ relationship is well documented (e.g., Borlace et al. 2014; Kidwell et al. 2016; Kiladis et al. 1989; Vincent et al. 2011 and others), this analysis served as a case study to test the performance of 20CRv2c with regard to ENSO variability.

For the mean DJF SPCZ position, the "canonical" north and east movement during El Niño conditions, and south and west displacement during La Niña conditions was observed. This pattern was enhanced during strong ENSO conditions (strongest $20 \%$ for both El Niño and La Niña) with the average SPCZ position moving significantly northeast during strong El Niño conditions, and significantly southwest during strong La Niña conditions (Fig. 5). This is in line with previous studies and remains consistent back to 1908, suggesting that 20CRv2c produces a realistic depiction of ENSOrelated southwest Pacific large-scale circulation for the entirety of the twentieth and early twenty-first century.

In addition to the ENSO-related positional changes, a distinct ENSO pattern was also seen in the intensity of the SPCZ. During El Niño conditions the maximum intensity shifts toward the IDL, and the overall intensity of the SPCZ also increases in comparison to other ENSO phases (Fig. 6). This pattern is prominent during strong El Niño conditions, but also exists during weak El Niño conditions. During La Niña conditions, maximum intensity occurs at the far western edge of the region $\left(150^{\circ} \mathrm{E}\right)$ and the magnitude is noticeably reduced during El Niño conditions. This pattern of maximum convection movement is likely a result of ENSO-related changes in trade winds and SSTs, and is noted in various studies (e.g., Borlace et al. 2014; Brown et al. 2011; Kidwell et al. 2016; Vincent et al. 2011).

The analysis performed indicated that the welldocumented ENSO-SPCZ relationship remains consistent through the twentieth and early twenty-first century when using the 20CRv2c DJF 500-hPa omega field. Previous documentation of this relationship has largely been confined to the satellite era since 1979 . This result suggests that the extended 20CRv2c product captures large-scale tropical Pacific atmospheric variability very well, back to at least 1908 . This suggests the potential to use $20 \mathrm{CRv} 2 \mathrm{c}$ and future iterations for examining long-term SPCZ and ENSO history. 
Overall, it is encouraging that the $20 \mathrm{CR}$ products perform well during 1979-2011 when analyzing the SPCZ. The similar depiction of the mean DJF SPCZ position relative to other reanalysis and satellite products is reinforced by strong spatial and temporal correlations. Improvements in the early 20CRv2 time span (1908-57) was likely the result of modest additions (five extra stations) to the underlying data assimilated between 20CR product iterations. This should encourage further data rescue efforts in the Southern Hemisphere to support continual improvement of the performance of the extended Twentieth Century Reanalysis. Likewise, testing the efficacy of additional observations added to the reanalysis for depicting the general circulation in a similar manner could be extended to other locations in the Southern Hemisphere, where there is a rich historic weather data resource available from ship log books (Chappell and Lorrey 2014).

Acknowledgments. This work was supported by the NIWA core funded project "Climate Present and Past" Contracts CAOA1701 and CAOA1801 and the Royal Society of New Zealand Marsden Fund Contract UOA1105 "Detecting prehistoric human-climate dynamics in central Polynesia using high-precision marine archives." This paper is also a contribution to the Atmospheric Circulation Reconstructions over Earth (ACRE) initiative from the ACRE Pacific chapter.

\section{REFERENCES}

Adler, R. F., and Coauthors, 2003: The version-2 Global Precipitation Climatology Project (GPCP) Monthly Precipitation Analysis (1979-present). J. Hydrometeor., 4, 1147-1167, https://doi.org/ 10.1175/1525-7541(2003)004<1147:TVGPCP >2.0.CO;2.

Borlace, S., A. Santoso, W. Cai, and M. Collins, 2014: Extreme swings of the South Pacific Convergence Zone and the different types of El Niño events. Geophys. Res. Lett., 41, 4695-4703, https://doi.org/10.1002/2014GL060551.

Brown, J. R., S. B. Power, F. P. Delage, R. A. Colman, A. F. Moise, and B. F. Murphy, 2011: Evaluation of the South Pacific convergence zone in IPCC AR4 climate model simulations of the twentieth century. J. Climate, 24, 1565-1582, https://doi.org/ 10.1175/2010JCLI3942.1.

_ - A. F. Moise, and F. P. Delage, 2012: Changes in the South Pacific Convergence Zone in IPCC AR4 future climate projections. Climate Dyn., 39, 1-19, https://doi.org/10.1007/ s00382-011-1192-0.

,-- , and R. A. Colman, 2013: The South Pacific convergence zone in CMIP5 simulations of historical and future climate. Climate Dyn., 41, 2179-2197, https://doi.org/10.1007/s00382012-1591-x.

Cai, W., and Coauthors, 2012: More extreme swings of the South Pacific convergence zone due to greenhouse warming. Nature, 488, 365-369, https://doi.org/10.1038/nature11358.

Chappell, P. R., and A. M. Lorrey, 2014: Identifying New Zealand, Southeast Australia, and Southwest Pacific historical weather data sources using Ian Nicholson's Log of Logs. Geosci. Data J., 1, 49-60, https://doi.org/10.1002/gdj3.1.

Collins, M., and Coauthors, 2010: The impact of global warming on the tropical Pacific Ocean and El Niño. Nat. Geosci., $\mathbf{3}$ 391-397, https://doi.org/10.1038/ngeo868.

Compo, G. P., and Coauthors, 2011: The Twentieth Century Reanalysis project. Quart. J. Roy. Meteor. Soc., 137, 1-28, https:// doi.org/10.1002/qj.776.

Cram, T. A., and Coauthors, 2015: The International Surface Pressure Databank version 2. Geosci. Data J., 2, 31-46, https:// doi.org/10.1002/gdj3.25.

Dee, D. P., and Coauthors, 2011: The ERA-Interim reanalysis: Configuration and performance of the data assimilation system. Quart. J. Roy. Meteor. Soc., 137, 553-597, https://doi.org/10.1002/qj.828.

Diamond, H. J., A. M. Lorrey, and J. A. Renwick, 2013: A southwest Pacific tropical cyclone climatology and linkages to the El Niño-Southern Oscillation. J. Climate, 26, 3-25, https://doi.org/10.1175/JCLI-D-12-00077.1.

Folland, C., J. Renwick, M. Salinger, and A. Mullan, 2002: Relative influences of the interdecadal Pacific oscillation and ENSO on the South Pacific convergence zone. Geophys. Res. Lett. 29, 1643, https://doi.org/10.1029/2001GL014201.

Haffke, C., and G. Magnusdottir, 2013: The South Pacific Convergence Zone in three decades of satellite images. J. Geophys. Res. Atmos., 118, 10 839-10 849, https://doi.org/ 10.1002/jgrd.50838.

Hubert, L. F., 1961: A subtropical convergence line of the South Pacific: A case study using meteorological satellite data. J. Geophys. Res., 66, 797-812, https://doi.org/10.1029/ JZ066i003p00797.

Huffman, G. J., and Coauthors, 2007: The TRMM Multisatellite Precipitation Analysis (TMPA): Quasi-global, multiyear, combinedsensor precipitation estimates at fine scales. J. Hydrometeor., 8 , 38-55, https://doi.org/10.1175/JHM560.1.

IPCC, 2013: Climate Change 2013: The Physical Science Basis. Cambridge University Press, 1535 pp., https://doi.org/10.1017/ CBO9781107415324.

Kalnay, E., and Coauthors, 1996: The NCEP/NCAR 40-Year Reanalysis Project. Bull. Amer. Meteor. Soc., 77, 437-471, https:/ doi.org/10.1175/1520-0477(1996)077<0437:TNYRP>2.0.CO;2.

Kidwell, A., T. Lee, Y.-H. Jo, and X.-H. Yan, 2016: Characterization of the variability of the South Pacific convergence zone using satellite and reanalysis wind products. J. Climate, 29, 1717-1732, https://doi.org/10.1175/JCLID-15-0536.1.

Kiladis, G. N., H. Von Storch, and H. Loon, 1989: Origin of the South Pacific convergence zone. J. Climate, 2, 1185-1195, https:// doi.org/10.1175/1520-0442(1989)002<1185:OOTSPC > 2.0.CO;2.

Liebmann, B., and C. A. Smith, 1996: Description of a complete (interpolated) outgoing longwave radiation dataset. Bull. Amer. Meteor. Soc., 77, 1275-1277.

Lintner, B. R., and J. D. Neelin, 2008: Eastern margin variability of the South Pacific convergence zone. Geophys. Res. Lett., 35 , L16701, https://doi.org/10.1029/2008GL034298.

Lorrey, A., G. Dalu, J. Renwick, H. Diamond, and M. Gaetani, 2012: Reconstructing the South Pacific convergence zone position during the presatellite era: A La Niña case study. Mon. Wea. Rev., 140, 3653-3668, https://doi.org/10.1175/MWR-D11-00228.1.

Madden, R. A., and P. R. Julian, 1994: Observations of the 40-50-day tropical oscillation-A review. Mon. Wea. Rev., 122, 814-837, https://doi.org/10.1175/1520-0493(1994)122<0814: OOTDTO $>2.0 . \mathrm{CO} ; 2$. 
Matthews, A. J., 2012: A multiscale framework for the origin and variability of the South Pacific Convergence Zone. Quart. J. Roy. Meteor. Soc., 138, 1165-1178, https://doi.org/10.1002/qj.1870.

_ - B. J. Hoskins, J. M. Slingo, and M. Blackburn, 1996: Development of convection along the SPCZ within a Madden-Julian oscillation. Quart. J. Roy. Meteor. Soc., 122, 669-688, https:// doi.org/10.1002/qj.49712253106.

McPhaden, M. J., S. E. Zebiak, and M. H. Glantz, 2006: ENSO as an integrating concept in earth science. Science, 314, 1740-1745, https://doi.org/10.1126/science.1132588.

Niznik, M. J., B. R. Lintner, A. J. Matthews, and M. J. Widlansky, 2015: The role of tropical-extratropical interaction and synoptic variability in maintaining the South Pacific convergence zone in CMIP5 models. J. Climate, 28, 3353-3374, https://doi.org/ 10.1175/JCLI-D-14-00527.1.

Streten, N. A., and A. Troup, 1973: A synoptic climatology of satellite observed cloud vortices over the Southern Hemisphere. Quart. J. Roy. Meteor. Soc., 99, 56-72, https://doi.org/ 10.1002/qj.49709941906.

Takahashi, K., and D. S. Battisti, 2007: Processes controlling the mean tropical Pacific precipitation pattern. Part II: The SPCZ and the southeast Pacific dry zone. J. Climate, 20, 5696-5706, https://doi.org/10.1175/2007JCLI1656.1.

Trenberth, K. E., 1976: Spatial and temporal variations of the Southern Oscillation. Quart. J. Roy. Meteor. Soc., 102, 639-653, https://doi.org/10.1002/qj.49710243310.

_ , and Coauthors, 2007: Observations: Surface and atmospheric climate change. Climate Change 2007: The Physical Science Basis, S. Solomon et al., Eds., Cambridge University Press, 235-336.
Van Der Wiel, K., A. J. Matthews, D. P. Stevens, and M. M. Joshi, 2015: A dynamical framework for the origin of the diagonal South Pacific and South Atlantic convergence zones. Quart. J. Roy. Meteor. Soc., 141, 1997-2010, https://doi.org/10.1002/ qj.2508.

,-- M. M. Joshi, and D. P. Stevens, 2016: The influence of diabatic heating in the South Pacific Convergence Zone on Rossby wave propagation and the mean flow. Quart. J. Roy. Meteor. Soc., 142, 901-910, https://doi.org/10.1002/qj.2692.

Vincent, D. G., 1994: The South Pacific convergence zone (SPCZ): A review. Mon. Wea. Rev., 122, 1949-1970, https://doi.org/ 10.1175/1520-0493(1994)122<1949:TSPCZA>2.0.CO;2.

Vincent, E. M., M. Lengaigne, C. E. Menkes, N. C. Jourdain, P. Marchesiello, and G. Madec, 2011: Interannual variability of the South Pacific Convergence Zone and implications for tropical cyclone genesis. Climate Dyn., 36, 1881-1896, https://doi.org/10.1007/s00382-009-0716-3.

Wang, C., C. Deser, J.-Y. Yu, P. DiNezio, and A. Clement, 2017: El Niño and Southern Oscillation (ENSO): A review. Coral Reefs of the Eastern Tropical Pacific: Persistence and Loss in a Dynamic Environment, P. W. Glynn, D. Manzello, and I. C. Enochs, Eds., Springer, 85-106.

Widlansky, M. J., P. J. Webster, and C. D. Hoyos, 2011: On the location and orientation of the South Pacific Convergence Zone. Climate Dyn., 36, 561-578, https://doi.org/10.1007/ s00382-010-0871-6.

Wolter, K., and M. S. Timlin, 1998: Measuring the strength of ENSO events: How does 1997/98 rank? Weather, 53, 315-324, https://doi.org/10.1002/j.1477-8696.1998.tb06408.x. 